\title{
GEOLOGY
}

DOI https://doi.org/10.30525/978-9934-26-183-1-23

\section{АСПЕКТИ ПЕРЕРОЗПОДІЛУ ГАЗУ У ВУГЛЕПОРОДНОМУ МАСИВІ ДОНЕЦЬКОГО БАСЕЙНУ}

\author{
Вергельська Н. В. \\ доктор геологічних наук, \\ стариий науковий співробітник, \\ завідувач відділу гірничої геоекології
}

Державна установа «Науковий центр гірничої геології, геоекології та розвитку інфраструктури Національної академії наук Украӥни»

\section{Скопиченко I. M.}

кандидат геолого-мінералогічних наук, старший науковий співробітник

Державна установа «Науковий центр гірничої геології, геоекології та розвитку інфраструктури Національної академії наук України»

Вергельська В. В.

аспірант

Державна установа «Інститут геохімї навколишнього середовища Національної академії наук України»

м. Київ, Україна

Значні ресурси газу вугільних родовищ у вугільних басейнах України використовуються лише на окремих шахтах Донбасу, коли метанова частка сягає понад 25\%, в переважній більшості 33-36\%, всієї газової суміші. Якісні характеристики газової суміші вугільних родовищ постійно змінюється за розрізом і падінням пласта та, особливо чітко, вирізняє тектонічно порушені зони у вугільних пластах. При відпрацюванні вугільних пластів створюються нові шляхи міграції вуглеводнів та колектори, які перевершують попередні за об'ємами та пористістю, сприяють перерозподілу газоносності у вуглепородному масиву.

Дослідження природи та складу вугільних газів, їх поширення у вугільних пластах, вміщуючих породах та відпрацьованих просторах на 
сьогодні $є$ актуальним для вуглевидобувних підприємств та вугільної геології $[1,2,8]$.

Протягом 2011 - 2021 років було проведено ряд польових i лабораторних досліджень газових сумішей у вуглепородних масивах Донецького басейну, переважно в Донецько-Макіївському, Красноармійському та Павлоградському вуглепромислових районах. За результатами аналізу проб встановлену якісну і кількісну газову складову у вуглепородному масиві.

Сучасний стан газонасиченості вуглепородного масиву Донецького басейну $\epsilon$ результатом тектонічних процесів які $\epsilon$ син- та постгенетичними відносно періодів формування вугільних пластів. Глибинна будова та аналіз матеріалів 3 історії геологічного розвитку Донецького вугільного басейну свідчить, що утворення і формування складчастих форм масиву відбувалося протягом всієї геологічної історії розвитку регіону. Перерозподіл газонасичених зон та шляхів міграції у вуглепородних масивах продовжується й тепер, що пов'язано як із сучасною міграцією флюїдів так і з формуванням техногенних колекторів при відпрацюванні вугільних покладів. При визначенні газонасичених зон варто враховувати водоносні горизонти вуглепородних масивів, які можуть виступати як транспортні артерії для переміщення водо-газових розчинів. Оскільки вода може як поглинати газові суміші так і віддавати гази при зміні температури у вуглепородних масивах. Температура також впливає на якісні та кількісні характеристики газу, які мігрують вертикально та можуть вступати в дію з породами масиву.

Вивчаючи якість вугілля для різноманітного його використання в промисловості, багато дослідників відмічали суттєві зміни деяких фізико-хімічних та енергетичних показників вугілля в контактових зонах магматичних комплексів. Вугілля, що підпало у природних умовах під високотемпературні зміни, характеризується зміною ступеню відбивної здатності вітриніту, зниженими показниками теплоти згорання, збільшеними показниками зольності та карбонатності. 3 вказаного переліку змін вихідних показників вугільної речовини видно, яку глибоку трансформацію набувають вугільні пласти за умов магматермальної дії. За проникнення інтрузій відмічається спікання вугілля до середньотемпературного коксу, а в деяких місцях навіть заміщення вугільних пластів інтрузивним дайковим комплексом, що також має значний вплив як на газові суміші та i на їх розподіл у вуглепородному масиві [3-7].

Внаслідок зміни гіпсометричних рівнів вугільних товщ, у постформаційний період, відбуваються зміна складу і перерозподіл зон газо- 
насичення масиву. При активізації тектонічних рухів у вуглепородних масивах створювалися нові структури для природної дегазації, акумуляції та збереження газу. Це частково пояснює чому гази, серед яких і метан, у вугільній товщі поширені нерівномірно. Одним з головних факторів нерівномірного поширення газу у вуглепородному масиві $\epsilon$ характер розповсюдження сучасних геологічних структур, в яких розташовані вугленосні поклади. Газоносність вугільних пластів контролюється геологічними структурами, де простежується чіткий взаємозв'язок: газоносність вугільних пластів визначається наявністю дрібних структур різного характеру $[1,4,6]$ в яких газові поклади пов'язані з вугільними пластами та вміщуючими їх породами.

Зважаючи на те, що вуглеводні метанового ряду, крім частини метану 3 проблематичною генетикою, синтезовані у більш жорстких термобаричних умовах ніж сучасні умови їх поширення [4], можна стверджувати, газонасичення вугільного масиву відбулося за рахунок конвективної дифузії газової суміші тріщинами розривних порушень, тобто за рахунок переносу речовини рухомим середовищем. Рух потоку речовини відбувався у відповідності до другого закону термодинаміки, згідно якому стан речовини змінюється у напрямку досягнення рівноваги температури і тиску - з глибоких горизонтів до приповерхневих, від високих температур і тиску - до більш низьких.

При проведенні гірничих робіт порушується рівновага системи газ вміщуюче середовище, створене попередніми геологічними процесами. У відпрацьованому просторі діючих шахт створюється новий газовий колектор, який має більш пористу структуру та більший розмір, ніж потужність вугільного пласта.

Отже, умови насичення та перерозподілу газу у вуглепородному масиві Донбасу насиченими $\left(\mathrm{C}_{3}-\mathrm{C}_{5}\right)$ та ненасиченими $\left(\mathrm{C}_{2}\right)$ вуглеводнями визначаються величиною періодів збільшення чи зменшення пропускної здатності тектонічних розривних порушень з часом надходження до них вуглеводнів.

\section{Література:}

1. Вергельська Н. В., Правоторова О. В., Назарова I. О. Про особливості газової складової вугільних пластів в тектонічно активних зонах (на прикладі ділянки Північно-Родинська-2 ДП ВК «Краснолиманська»). Наукові праџуі УкрНДМІ НАН Украӥни. 2011. Вип. 9. Ч. 2. С. 440-450. 
2. Вергельська Н. В. Газоносність відпрацьованого простору діючих шахт Донбасу. Тектоніка $і$ стратиграфія. 2012. Вип. 39. C. $30-33$.

3. Гуревич А. Б. , Гаврилова О. И., Шишков С. Б. Методика прогнозирования качества углей в бассейнах $\mathrm{c}$ интенсивным магматизмом. Сов. геология. 1987. № 7. С. 3-11.

4. Майданович И. А., Радзивилл А. Я. Особенности тектоники угольных бассейнов Украины. Киев: Наук. думка, 1984. 120 с.

5. Сукачев А. Н., Радзивилл А. Я., Касьянов В. В., Сусло А. И. Опыт исследования ацетиленоносности угольных пластов шахт Донецко-Макеевского района. Киев. 1992. 55 с.

6. Радзівілл А. Я. До прогнозу зміни метаноносності вугленосних відкладів Складчастого Донбасу з глибиною. Наук. пращуі Інституту фундаментальних досліджень. Київ: Знання. 2001. С. 105-110.

7. Радзівілл А.Я., Іванова А.В., Зайцева Л.Б. Геологія вуглегазових басейнів (провінцій) України. Київ: ЛОГОС. 2007. 179 с.

8. Тиркель М.Г., Анциферов В.А., Глухов А.А. Изучение газоносности угленосной толщи. Донецк: ВЕБЕР. 2008. 208 с. 